\title{
Histopathological Changes in the Gill and Liver Tissues of Freshwater Fish, Cirrhinus mrigala Exposed to Dichlorvos
}

\author{
Babu Velmurugan ${ }^{1}$, Mariadoss Selvanayagam ${ }^{1}$, Elif Ipek Cengiz ${ }^{2 *}$ and Erhan Unlu ${ }^{2}$ \\ ${ }^{1}$ Environmental Science and Biotechnology Research Unit; Department of Zoology; Loyola College; Chennai- 600 \\ 034; Tamil Nadu - India. ${ }^{2}$ Department of Biology; Section of Hydrobiology; Faculty of Science and Art; Dicle \\ University; 21280; Diyarbakir - Turkey
}

\begin{abstract}
The histopathological effects of dichlorvos, an organophosphate pesticide, on the gill and liver tissues in Cirrhinus mrigala were determined by light microscopy. The fishes were exposed to sublethal concentrations $(0.91$ and 1.82 ppm) of dichlorvos for 10 days with parallel untreated control. No histopathological effects were observed in control group. Hyperplasia, desquamation, and necrosis of epithelial, epithelial lifting, oedema, lamellar fusion, collapsed secondary lamellae, curling of secondary lamellae and aneurism in the secondary lamellae were observed in gill tissues exposed to dichlorvos. Hepatic lesions in the liver tissues of fishes exposed to dichlorvos were characterized by cloudy swelling of hepatocytes, congestion, vacuolar degeneration, karyolysis, karyohexis, dilation of sinusoids and nuclear hypertrophy.
\end{abstract}

Key words: Dichlorvos; Organophosphate pesticide; Cirrhinus mrigala; Histopathology

\section{INTRODUCTION}

India is primarily an agro-based country with more than $60-70 \%$ of its population dependent on agriculture. However, $30 \%$ of its agricultural produce is lost owing to pest infestation. In the absence of a better alternative, deployment of pesticides becomes inevitable despite their known hazardous effects. Utilization of pesticides in India is about $3 \%$ of the total world consumption and is increasing at the rate of $2-5 \%$ per annum (Bhadbhade et al., 2002).

Organophosphorus (OP) pesticides are finding increasing use in recent years since they are biodegradable and therefore persist in the environment only for a short time. Because of their low persistence, repeated applications of these pesticides are being practiced for the control of pests in agricultural fields and thereby large quantities find their way into water bodies (Jyothi and Narayan, 1999).

A large number of pesticides are commonly used to control various agricultural pests; however, their toxicological impact also extends to nontarget species like fish (Naqvi and Vaishnavi, 1993). Fish is good indicator of aquatic contamination because its biochemical stress responses are quite similar to those found in mammals (Mishra and Shukla, 2003).

Dichlorvos is an organophosphate pesticide (OP) commonly used in fish farming to eradicate crustacean ectoparasites. It is especially used in the treatment of sea lice (Lepophtheirus salmonis and Caligus elogatus) on commercial salmon

*Author for correspondence: ecengiz@dicle.edu.tr 
farms (Varò et al., 2003) and to control household, public health, and stored product insects. The Environmental Protection Agency (EPA) has classified dichlorvos as toxicity class I - highly toxic (URL:1).

The assessment of the ecotoxicological risks caused by pesticides to ecosystems is based on data on the toxicity and effects of pesticide preparations to non-target organisms. Fishes are among the group of non-target aquatic organisms.

Histological changes provide a rapid method to detect effects of irritants, especially chronic ones, in various tissues and organs (Bernet et al., 1999). Limited histopathlogical studies have been reported in treatment with dichlorvos (Benarji and Rajebdranath, 1991). Therefore, it was decided to determine the histopathological effects on gill and liver tissues in Cirrhinus mrigala chronically exposed to dichlorvos.

\section{MATERIALS AND METHODS}

C. mrigala were obtained from a fish farm in Tamil Nadu provice, India, which has no agricultural land or industries nearby. They weighed $9.36 \mathrm{~g} \pm 0.56$ (mean $\pm \mathrm{SD}$ ) and their length was in the range $6-8 \mathrm{~cm}$. The fishes were acclimated to the laboratory conditions for at least 20 days prior to the experiment in a glass aquarium (150 1) filled with dechlorinated water. Water quality characteristics were determined, which were as follows: temperature $27.5 \pm 1.5{ }^{\circ} \mathrm{C}$, $\mathrm{pH} 7.5 \pm 0.03$, dissolved oxygen $6.4 \pm 0.2 \mathrm{mg} / \mathrm{l}$, alkalinity $250 \pm 2.8 \mathrm{mg} / \mathrm{l}$ as $\mathrm{CaCO}_{3}$, total hardness $456 \pm 3.5 \mathrm{mg} / \mathrm{l}$. The fishes were fed daily with commercially balanced fish food sticks and maintained on a photoperiod $12 \mathrm{~h} / 12 \mathrm{~h}$ (light/dark) cycle.

Commercial grade dichlorvos (76\% EC) (Hindustan Ciba Geigy Ltd., Mumbai, India) was used in this study.
Renewal toxic test methods (APHA, 1995) were done to find out the 96-h $\mathrm{LC}_{50}$ concentration, which was $9.1 \mathrm{ppm}$. The fishes were divided into three groups and placed in separate glass aquaria. Fifteen fishes were used for each group. Groups I and II were exposed to sublethal concentrations of dichlorvos. Group III was maintained in pesticidefree water to serve as control. The nominal concentrations of dichlorvos tested were $0.91 \mathrm{ppm}$ and $1.82 \mathrm{ppm}$. These concentrations were chosen because they were lower than the lethal concentrations for $C$. mrigala.

After treatment, both the experimental and control fish were sacrificed at the end of $10^{\text {th }}$ day. Gill and liver tissues were removed and put in aqueous Bouins fluid. After fixation for 24-30 h, tissues were dehydrated through a graded series of ethanol, cleared in xylene, and infiltrated in the paraffin. Sections of 4-6 $\mu \mathrm{m}$ were prepared from paraffin blocks by using a rotary microtome. These sections were then stained with Hematoxylin-Eosin. Histopathological lesions were examined and photographed using Leica photomicroscope.

\section{RESULTS}

No histopathological changes were observed in the gill of the control fish. The structural details of the gill of control C. mrigala are shown in Fig. 1A. The most common changes in both 0.91ppm and $1.82 \mathrm{ppm}$ concentrations of dichlorvos were hyperplasia, desquamation, and necrosis of epithelial, epithelial lifting, oedema, lamellar fusion, collapsed secondary lamellae and curling of secondary lamellae. At exposure to dichlorvos at $0.91 \mathrm{ppm}$, the gills of experimental fish showed also severe aneurism in the secondary lamellae with the rupture of the pillar cells (Figs. 1B-I). The histological changes noticed in the pesticide exposed and control fishes are shown in Table 1.

Table 1- Summarized histopathological effects in the gills of Cirrhinus mrigala exposed to dichlorvos and control fish.

\begin{tabular}{lccccccc}
\hline $\begin{array}{c}\text { concentration } \\
\text { ppm }\end{array}$ & $\begin{array}{c}\text { epithelial } \\
\text { hyperplasia }\end{array}$ & $\begin{array}{c}\text { epithelial } \\
\text { necrosis and } \\
\text { desquamation }\end{array}$ & $\begin{array}{c}\text { epithelial } \\
\text { lifting and } \\
\text { oedema }\end{array}$ & aneurism & $\begin{array}{c}\text { collapsed } \\
\text { secondary } \\
\text { lamellae }\end{array}$ & $\begin{array}{c}\text { lamellar } \\
\text { fusion }\end{array}$ & $\begin{array}{c}\text { curling of } \\
\text { secondary } \\
\text { lamellae }\end{array}$ \\
\hline Control & - & - & - & - & - & - & - \\
0.91 & + & + & + & + & ++ & ++ & + \\
1.82 & ++ & ++ & ++ & - & ++ & ++ & ++ \\
\hline
\end{tabular}

none $(-)$, mild $(+)$, moderate $(++)$, severe $(+++)$. 

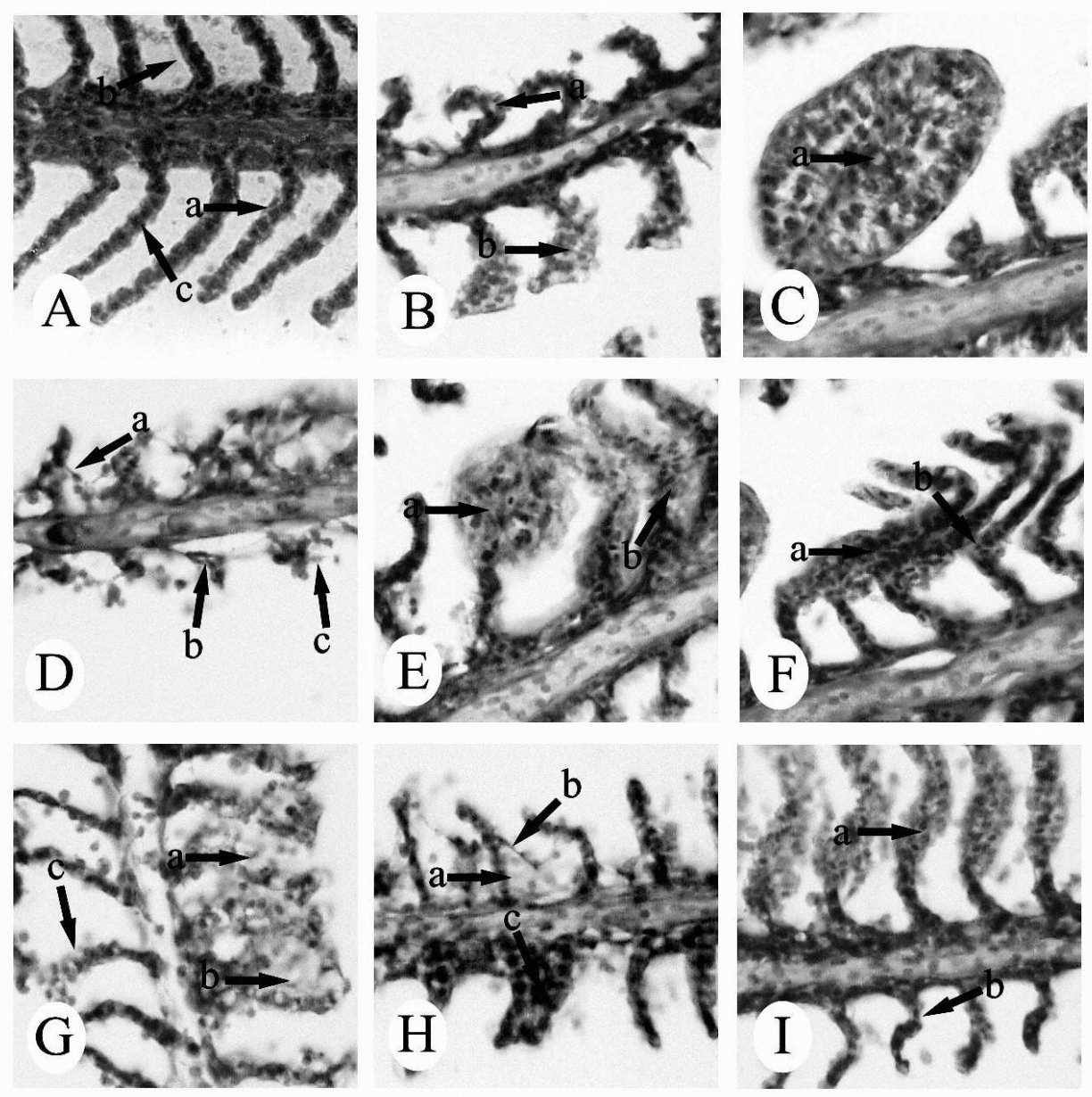

Figure 1 - Gill tissue of C. mrigala. (A) control - (a) epithelial cell, (b) secondary lamellae, (c) pillar cell. H\&E, x 250; (B) exposed to 0.91 ppm dichlorvos - (a) curling of secondary lamellae, (b) epithelial hyperplasia. H\&E, x 250; (C) exposed to $0.91 \mathrm{ppm}$ dichlorvos (a) aneurism. H\&E, x 250; (D) exposed to 0.91 ppm dichlorvos - (a) epithelial lifting, (b) collapsed secondary lamellae , (c) desquamation. H\&E, x 250; (E) exposed to 0.91 ppm dichlorvos - (a) aneurism, (b) epithelial hyperplasia and lamellar fusion. H\&E, $\mathrm{x}$ 250; (F) exposed to $0.91 \mathrm{ppm}$ dichlorvos - (a) lamellar fusion, (b) curling of secondary lamellae. H\&E, x 250; (G) exposed to 1.82 ppm dichlorvos - (a) desquamation, (b) oedema, (c) epithelial necrosis. H\&E, x 250; (H) exposed to 1.82 ppm dichlorvos - (a) oedema, (b) epithelial lifting, (c) lamellar fusion. H\&E, x 250; (I) exposed to $1.82 \mathrm{ppm}$ dichlorvos - (a) epithelial hyperplasia, (b) curling of secondary lamellae. H\&E, x 250.

No histopathological changes were observed in the liver of the control fish. The structural details of the liver of control C. mrigala are shown in Fig. 2A. In the liver tissues of fish exposed to dichlorvos concentrations of $0.91 \mathrm{ppm}$ and 1.82 ppm, cloudy swelling of hepatocytes, congestion, vacuolar degeneration, karyolysis, karyohexis, dilation of sinusoids and nuclear hypertrophy were seen (Figs. 2B-I). The histological changes noticed in the pesticide exposed and control fishes are shown in Table 2. 
Table 2 - Summarized histopathological effects in the liver of Cirrhinus mrigala exposed to dichlorvos and control fish.

\begin{tabular}{lccccccc}
\hline $\begin{array}{c}\text { concentration } \\
\text { ppm }\end{array}$ & $\begin{array}{c}\text { focal } \\
\text { necrosis }\end{array}$ & $\begin{array}{c}\text { cloudy } \\
\text { swelling of } \\
\text { hepatocytes }\end{array}$ & congestion & $\begin{array}{c}\text { vacuolar } \\
\text { degeneration }\end{array}$ & $\begin{array}{c}\text { karyolysis } \\
\text { and } \\
\text { karyohexis }\end{array}$ & $\begin{array}{c}\text { nuclear } \\
\text { hypertrophy }\end{array}$ & $\begin{array}{c}\text { dilation of } \\
\text { sinusoids }\end{array}$ \\
\hline control & - & - & - & & & & \\
0.91 & + & + & + & + & + & + & + \\
1.82 & ++ & ++ & + & + & ++ & ++ & ++ \\
\hline
\end{tabular}

none (-), mild (+), moderate $(++)$, severe $(+++)$.
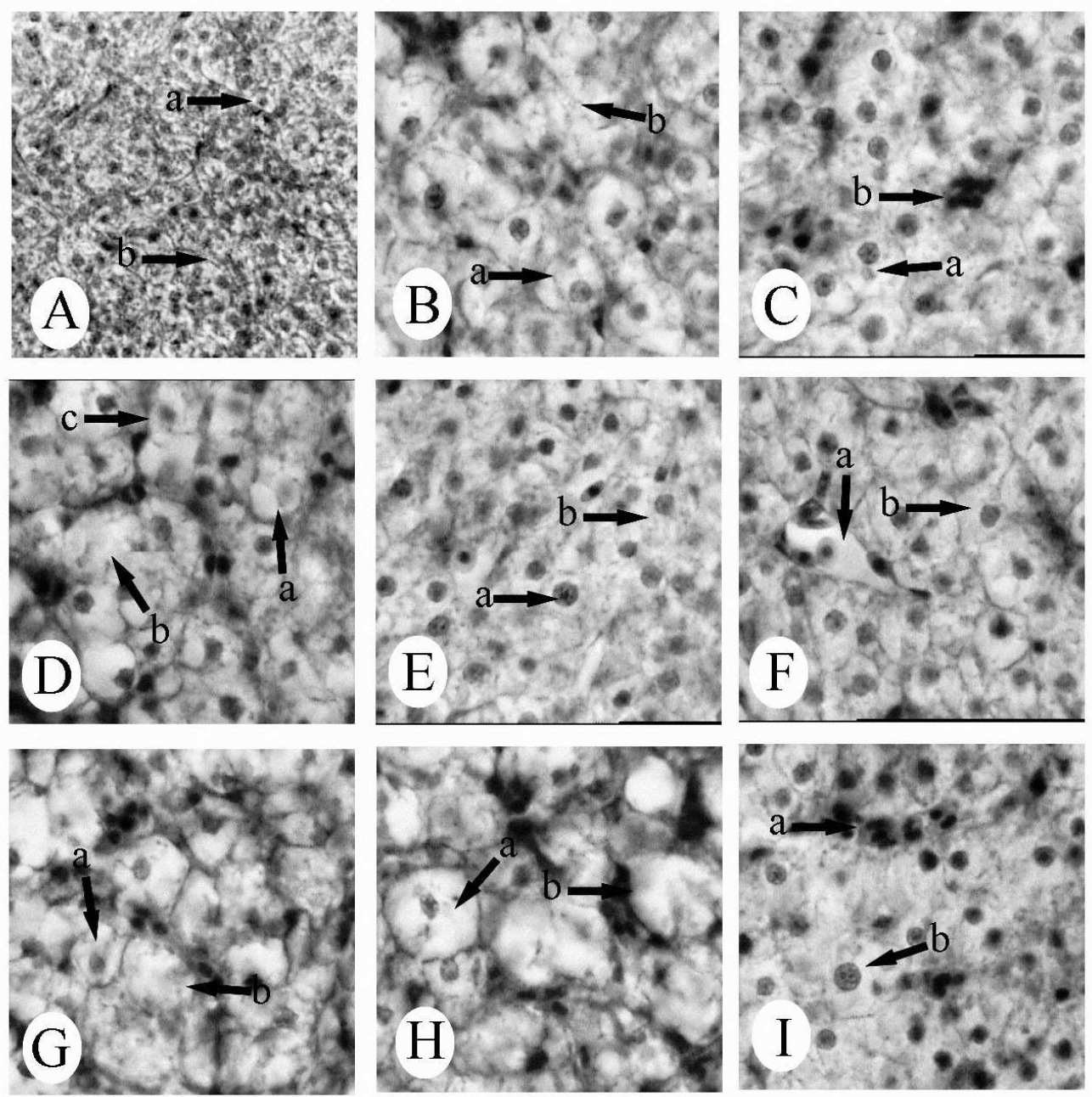

Figure 2 - Liver tissue of C. mrigala. (A) control - (a) hepatocyte, (b) sinusoid. H\&E, x 250; (B) exposed to $0.91 \mathrm{ppm}$ dichlorvos. (a) cloudy swelling of hepatocytes, (b) focal necrosis. $\mathrm{H} \& \mathrm{E}, \mathrm{x} 400$; (B) exposed to $0.91 \mathrm{ppm}$ dichlorvos - (a) vacuolar degeneration, (b) congestion. H\&E, x 400; (C) exposed to 0.91 ppm dichlorvos - (a) karyolysis, (b) focal necrosis, (c) karyohexis. H\&E, x 400; exposed to $0.91 \mathrm{ppm}$ dichlorvos - (a) nuclear hypertrophy, (b) cloudy swelling of hepatocytes. H\&E, x 400; (D) exposed to 1.82 ppm dichlorvos - (a) dilation of sinusoids, (b) cloudy swelling of hepatocytes. H\&E, $\mathrm{x}$ 400; (E) exposed to 1.82 ppm dichlorvos - (a) karyohexis, (b) karyolysis. H\&E, x 400; (H) exposed to $1.82 \mathrm{ppm}$ dichlorvos - (a) vacuolar degeneration, (b) focal necrosis. $\mathrm{H} \& \mathrm{E}$, x 400; (I) exposed to $1.82 \mathrm{ppm}$ dichlorvos. (a) nuclear hypertrophy, (b) congestion. H\&E, x 400 . 


\section{DISCUSSION}

Histopathological results indicated that gill was the primary target tissue affected by dichlorvos. Gills are generally considered good indicator of water quality (Rankin et al., 1982), being models for studies of environmental impact (Mallat, 1985; McKim and Erickson, 1991; Wenderlaar Bonga and Lock, 1992), since the gills are the primary route for the entry of pesticide. In fish, gills are critical organs for their respiratory, osmoregulatory and excretory functions.

Several other studies have shown similar effects of pesticides on fish gills (Cengiz and Unlu, 2002; 2003; Cengiz, 2006). Many investigators have reported the histopathological changes in gills of different fish species exposed to pesticides. Mucus extrusion, lamellar swelling, fused and reduced microridges, were observed in bluegill sunfish, Lepomis macrochirus to different sublethal concentrations of diazinon (Dutta et al., 1997). Histopathological effects of sublethal concentrations of monocrotophos on the gills of Anabas testudineus was reported by Santhakumar et al., (2001). Histopathological changes observed were hemorrhage in the primary and secondary gill lamellae, degeneration and necrosis of epithelial cells, distortion of the secondary lamellae, disruption of epithelial cells from pillar cells. Shorter gill lamellae, fusion, complete destruction of lamella, increased vacuolation, irregular appearance of gill lamellae were observed in guppy Poecilia reticulate exposed to chlorpyrifos (De Silva and Samayawardhena, 2002). Degenerative changes in gill, such as intraepithelial edema in the secondary lamellae, thick coating of mucus covering the entire gill filaments and lamellae, erosion of secondary lamellae, thickening of lamellae, inflammation of epithelial cells, breakages in primary lamellae, degeneration of secondary lamellae, necrosis, rupture of epithelium were noticed during exposure of sublethal concentrations of monocrotophos by Rao et al. (2005). Rao et al. (2006) observed uncontrolled regeneration of the primary lamellae and secondary lamellae, hypertrophy, hyperplasia, necrosis of the epithelial cells, epithelial lifting, dilation of the blood sinuses of the secondary lamellae, lamellar aneurism, hemorrhages in the gill of fish exposed to profenofos.
The liver is the main organ for detoxification (Dutta et al., 1993) that suffers serious morphological alterations in fish exposed to pesticides (Rodrigues and Fanta, 1998). Alterations in the liver may be useful as markers that indicate prior exposure to environmental stressors.

In another study, cloudy swelling, bile stagnation, focal necrosis, atropy and vacuolization have been reported in the Corydoras paleatus exposed to methyl parathion (Fanta et al., 2003). Hyperplasia, vacuolation, disintegrated blood vessels, disrupted hepatocytes, focal coagulative necrosis, disorganized hepatic canaliculi were observed by Sarkar et al. (2005) in Labeo rohita exposed to cypermethrin. Hepatic lesions in the liver tissues of fish Gambusia affinis exposed to deltamethrin were reported such as hypertrophy of hepatocytes, increase of Kupffer cells, circulatory disturbances, focal necrosis, fatty degeneration, nuclear pycnosis, narrowing of sinusoids (Cengiz and Unlu, 2006).

All the histopathological observation indicated that exposure to sublethal concentrations of dichlorvos caused destructive effect in the gill and liver tissues of $C$. mrigala. Gill and liver histopathological alterations, such as those observed in this study and findings from previous studies, could result in severe physiological problems, ultimately leading to the death of fish. As a conclusion, the findings of the present histological investigations demonstrated a direct correlation between pesticide exposure and histopathological disorders observed in several tissues.

\section{REFERENCES}

APHA (American Public Health Association) (1995), Standard methods for the examination of water and wastewater. Washington, DC.

Benarji, G.; Rajebdranath, T. (1991), Dichlorvosinduced histoarchitectural changes in the oocytes of a freshwater fish. Funct. Dev. Morphol., 1, 9-12.

Bernet, D.; Schmidt, H.; Meier, W.; Burkhardt-Holm, P.; Wahli, T. (1999), Histopathology in fish: proposal for a protocol to assess aquatic pollution. J. Fish Dis., 22, 25-34.

Bhadbhade, B. J.; Sarnaik, S. S.; Kanekar, P. P. (2002), Bioremediation of an industrial effluent containing monocrotophos. Curr. Microbiol., 45, 346-349. 
Cengiz, E. I.; Unlu, E. (2002), Histopathologica changes in the gills of mosquitofish, Gambusia affinis exposed to endosulfan. B. Environ. Contam. Tox., 68, 290-296.

Cengiz, E. I.; Unlu, E. (2003), Histopathology of gills in mosquitofish, Gambusia affinis after long-term exposure to sublethal concentrations of malathion. $J$. Environ. Sci. Heal. B, 38, 581-589.

Cengiz, E. I.; Unlu, E. (2006), Sublethal effects of commercial deltamethrin on the structure of the gill, liver and gut tissues of mosquitofish, Gambusia affinis: A microscopic study. Environ. Toxicol. Phar., 21, 246-253.

Cengiz, E. I. (2006), Gill and kidney histopathology in the freshwater fish Cyprinus carpio after acute exposure to deltamethrin. Environ. Toxicol. Phar., 22, 200-204.

De Silva, P. M. C. S.; Samayawardhena, L. A. (2002), Low concentrations of lorsban in water result in far reaching behavioral and histological effects in early life stages in guppy. Ecotox. Environ. Safe., 53, 248254.

Dutta, H. M.; Adhikari, N. K.; Singh, P. K.; Munshi, J. S. (1993), Histopathological changes induced by malathion in the liver of a freshwater catfish, Heteropneustes fossilis (Bloch). B. Environ. Contam. Tox., 51, 895-900.

Dutta, H. M.; Munshi, J. S. D.; Roy, P. K.; Singh, N. K.; Motz, L.; Adhikari, S. (1997), Effects of diazinon on bluegill sunfish, Lepomis macrochirus, gills: scanning electron microscope observations. Exp. Biol. Online, 2, 1-11.

Fanta, E.; Rios, F. S.; Romao, S.; Vianna, A. C. C.; Freiberger, S. (2003), Histopathology of the fish Corydoras paleatus contaminated with sublethal levels of organophosphorus in water and food. Ecotox. Environ. Safe., 54, 119-130.

Jyothi, B.; Narayan, G. (1999), Certain pesticideinduced carbohydrate metabolic disorders in the serum of freshwater fish Clarias batrachus (Linn.). Food. Chem. Toxicol., 37, 417-421.

Mallat, J. (1985), Fish gill structural changes induced by toxicants and other irritants: a statistical review. Can. J. Fish Aquat. Sci., 42, 630-648.

McKim, J. M.; Erickson, R. J. (1991), Environmental impacts on the physiological mechanisms controlling xenobiotic transfer across fish gills. Physiol. Zool., 64, 39-67.
Mishra, R.; Shukla, S. P. (2003), Endosulfan effects on muscle malate dehydrogenase of the freshwater catfish Claria batrachus. Ecotox. Environ. Safe., 56, 425-433.

Naqvi, S. M.; Vaishnavi, C. (1993), Bioaccumulative potential and toxicity of endosulfan insecticide to non-target animals. Comp. Biochem. Phys. C, 105, 347-361.

Rankin, J. C.; Atagg, R. M.; Bolis, L. (1982), Effects of pollutants on gills. In-Gills, eds. D. F. Houlihan, J. C. Rankin, T. J., Shuttleworth. Cambridge University Press, New York, pp. 207-220.

Rao, J. V.; Begum, G.; Sridhar, V.; Reddy, N. C. (2005), Sublethal effects of monocrotophos on locomotor behavior and gill architecture of the mosquito fish, Gambusia affinis. J. Environ. Sci. Heal. B, 40, 813-825.

Rao, J. V.; Begum, G.; Jakka, N. M.; Srikanth, K.; Rao, R. N. (2006), Sublethal effects of profenofos on locomotor behavior and gill architecture of the mosquito fish, Gambusia affinis. Drug. Chem. Toxicol., 29, 255-267.

Rodrigues, E. L.; Fanta, E. (1998), Liver histopathology of the fish Brachydanio rerio after acute exposure to sublethal levels of the organophosphate dimethoat 500. Rev. Bras. Zool., 15, 441-450.

Santhakumar, M.; Balaji, M.; Ramudu, K. (2001), Gill lesions in the perch, Anabas testudineus, exposed to monocrotophos. J. Environ. Biol., 22, 87-90.

Sarkar, B.; Chatterjee, A.; Adhikari, S.; Ayyappan, S. (2005), Carbofuran and cypermethrin induced histopathological alterations in the liver of Labeo rohita (Hamilton) and its recovery. J. Appl. Ichthyol., 21, 131-135.

URL:1:http://pmep.cce.cornell.edu/profiles/extoxnet/car baryl-dicrotophos/dichlorvos-ext.html

Varò, I.; Navarro, J. C.; Amat, F.; Guilhermino, L. (2003), Effect of dichlorvos on cholinesterase activity of the European sea bass (Dicentrarchus labrax). Pestic. Biochem. Phys., 75, 61-72.

Wenderlaar Bonga, S. E.; Lock, A. A. C. (1992), Toxicants and osmoregulation in fish. Neth. J. Zool., 42, 478-493. 